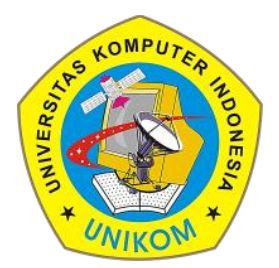

\title{
Aesthetic Study of Malioboro Yogyakarta Trash Can
}

\author{
Ifan Rohimanto ${ }^{1}$, Yeffry Handoko Putra ${ }^{2}$ \\ ${ }^{1}$ Program Studi Magister Desain Fakultas Pascasarjana Universitas Komputer Indonesia \\ ${ }^{2}$ Program Studi Magister Sistem Informasi Fakultas Pascasarjana Universitas Komputer Indonesia \\ Jl. Dago (Ir. H. Djuanda) 160 - 162, Bandung, 40132 \\ email : $\underline{\text { ifanrohimanto@gmail.com }}$
}

\begin{abstract}
Malioboro Street in Special Region of Yogyakarta, Indonesia is a tourist area. Both sidewalks on the street facilitated with garden chairs, ornamental plants, ornamental statues, ready to drink tap water, and trash cans. Product aesthetic of Malioboro trash cans is important to be studied since the product will be placed in public facility. Research on trash cans in Malioboro area was conducted to see the content of product aesthetic of the trash can. The analysis method uses the aesthetic theory of Dr. Dharsono, M.Sn (Sony Kartika), which consists of color, shape, texture and proportion.. The results showed the color and natural texture obtained from the aluminum, terrazzo, and sand/Merapi mountain ash. The shape consists of blocks/boxes and tubes with aluminum lids using traditional forging techniques namely kenteng, balanced proportions. Malioboro trash can has product aesthetic value that supports Malioboro tourist area.
\end{abstract}

Keywords: Aesthetics; Kenteng; Malioboro; Products; Trash Can. 


\title{
Aesthetic Study of Malioboro Yogyakarta Trash Can
}

\author{
Ifan Rohimanto \& Yeffry Handoko Putra
}

\section{Introduction}

Environmental hygiene conditions in people's lives are inseparable from public awareness in maintaining cleanliness from waste by using trash cans. The creation of trash cans is a form of concern in maintaining the health and preservation of environmental hygiene, the trash can is part of the waste management effort. Ineffective or irresponsible disposal of this waste can pollute the environment and pose a public health risk. We are running out of space in existing landfills (Rahman, 2014). The purpose and benefits of a trash can are the most important things in understanding a trash can. however, many people take this lightly. This is due to the lack of sympathy and awareness of residents with their environment (Jurang007, 2020).

Trash cans in the special region of Yogyakarta, has its own specialties, along with the arrangement of Malioboro street as a tourist area, trash cans as part of hygiene facilities are designed. The use of aluminum material on the cover of the trash can, and Terrazzo for the bottom is not as conspicuous as the trash can in general, but the shape blends with the beauty of pedestrians in the Malioboro area (see Figure 1).

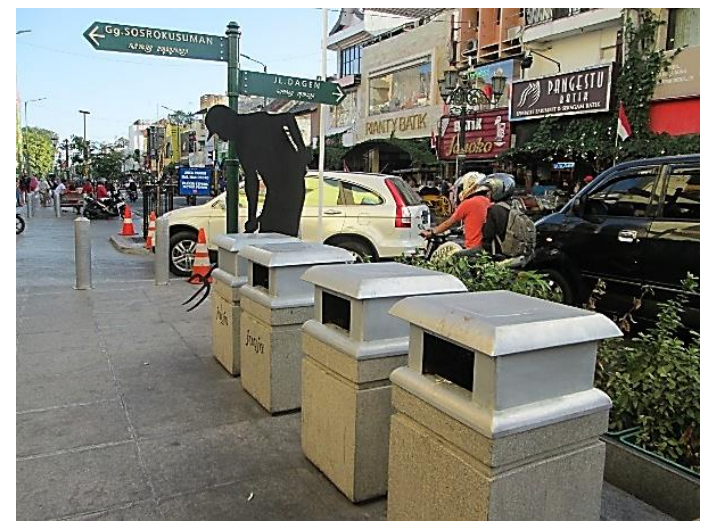

Figure 1. Trash can In Malioboro Area, Special Region of Yogyakarta Source: https://www.terusberjuang.com/2017/08/jogja-istimewa-yang-meng-indonesiadan-akan-mendunia.html

Materials and techniques used for trash cans in Malioboro sidewalk as an effort to meet human aesthetic needs in realizing a design product. The use of tools and techniques involves advanced technology, such as the use of manufacturer's trash cans of various shapes, colors and materials. But the trash can in malioboro sidewalk area is made with craftsmen skills using kenteng technique, which is a hitting technique to form aluminum material manually. "In Indonesian the word "kriya" means work (handicraft). In English it is called craft which means energy or strength. Then the term is defined as skill and is associated with a profession as seen in Copyright (c) 2020 Ifan Rohimanto, Yeffry Handoko Putra

(c) $($ ) $($ ) 


\title{
Aesthetic Study of Malioboro Yogyakarta Trash Can
}

\author{
Ifan Rohimanto \& Yeffry Handoko Putra
}

craftsworkers" (Haryono, 2002). "In fact, craft art is often intended as a work produced because of skill or skill" (Bandem 2002).

The beauty of Malioboro sidewalk is supported by its environment, Malioboro trash can facilities with trash can lids done through kenteng techniques have their own peculiarities and advantages, as an effort to preserve locality, also has its own aesthetic value. The Government of Special Region of Yogyakarta which has one of the missions of "strengthening urban planning and environmental sustainability" (Kota Yogyakarta, 2020) realizes that important aesthetic values are loaded for trash cans as part of the mission. People begin to include aesthetic components in every aspect of life therefore; the term of aesthetics takes part in many peoples' daily life (Weggeman et al., 2007; Venkatesh and Meamber, 2008). In this case, Newkirk and Crainer, (2003) stated, Aesthetics, one of the most significant ways to make world special, is the art of creating reactions that without words and communicate by way of sense.

Based on this, this research was conducted to analyze the aesthetics of the shape of the trash can in Malioboro sidewalk, Yogyakarta, the beauty of Malioboro sidewalk trash can is made with the aim of aligning with the beauty of the sidewalk environment as a tourist area, so as not to be conspicuous, so that the trash can is designed to blend with the environment. It is necessary to conduct research on the aesthetic content of the form of the trash can. What is the shape, color, size and choice of techniques and materials used, as well as whether the trash has a psychological impact on the audience, Consumers' aesthetic appraisal of products is related to whether a product design includes certain design properties such as color, shape, etc. (Blijlevens et al., 2012). Related to this Bloch (1995) explained that the form of product generates psychological reactions which include cognitive and emotional contents. These psychological reactions also cause behavioral responses which indirectly lead to behavioral responses. Therefore, marketers use product aesthetics as a tool for competitive differentiation (Cox and Cox, 2002).

\section{Method}

The research was conducted to parse the aesthetic value of the trash can contained in malioboro pedestrian city of Yogyakarta, using aesthetic method from Dr. Dharsono (Sony Kartika)(2007), namely analyzing artifacts into four indicators such as shape, texture, color, and proportions. The research object focuses on the design of trash cans located in the sidewalk area of Malioboro Yogyakarta in 2019. Aesthetic analysis of the trash can is limited to the lid only in the form of a box and made of aluminum made with kenteng technique. Data collection method through literature and observation. 


\title{
Aesthetic Study of Malioboro Yogyakarta Trash Can
}

\author{
Ifan Rohimanto \& Yeffry Handoko Putra
}

\section{Result(s) and Discussion}

\section{Trash cans as a Product}

Throughout human history, trash has undergone changes in shape and use of its materials, trash cans as part of the product, of course it has the form and function, form and function has become two main concepts in the discourse of product design. In this case Sumarjono (2005) stated, Aspects of the form has an important position because it represents the attractiveness that must exist in a product. Meanwhile, the function aspect has an important position because it represents the comfort and ease of operation of a product. Based on the shape of the trash can following its function, especially the trash cans used for the household environment, indoor and outdoor trash cans, wet trash cans and dry trash cans, Leblance (2020) states, there are outdoor trash cans (even ones designed to be resistant to raccoons, bears and other pests) as well as kitchen trash cans and ones created to meet the needs of a variety of other office and plant applications. Trash volume and composition is an important consideration.

The trash can is placed outdoors, serves as a place of merging all the garbage from the inside. In addition, there are also trash cans created as public facilities that are placed in a number of areas, including: shops, city parks, pedestrian paths, tourist attractions, and others. Waste management is important to manage waste in urban environments, waste management requires methods, as stated Rahman (2014), current disposal methods threaten our health, safety, and environment, and pose additional indirect costs to society. Trash cans as a container for managing waste placed on urban streets, the shape is not only to fulfill the function, but also to be part of the beauty of the city so that the forms of the trash can are also noticed. Urban communities are more concerned with cleanliness because trash cans that have aesthetic value can influence the community in maintaining this environment as stated by Herawati and Amri (2017), The use of patterned trash cans affects the behavior of elementary school students to dispose of waste in its appropriate place for paper types, plastic trash cans and bottles as well as trash cans and food waste. The trash can with its information easy to understand and the images are attractive to students".

Serious bins and waste management were first carried out in England, as stated by Hills (2019), Garbage collection became an official service in 1875 in England. Along with this were formalized bins where residents would dispose their ashes from burned household waste. As public health became more of a concern in London the city eventually passed the public health act of 1875 requiring all households to dispose their weekly wasted in movable receptacles for disposal, the modern trash can be found. In 1895 New York City would become the first U.S. city to have a similar public sector garbage management authority (see Figure 2). 


\section{Aesthetic Study of Malioboro Yogyakarta Trash Can}

Ifan Rohimanto \& Yeffry Handoko Putra

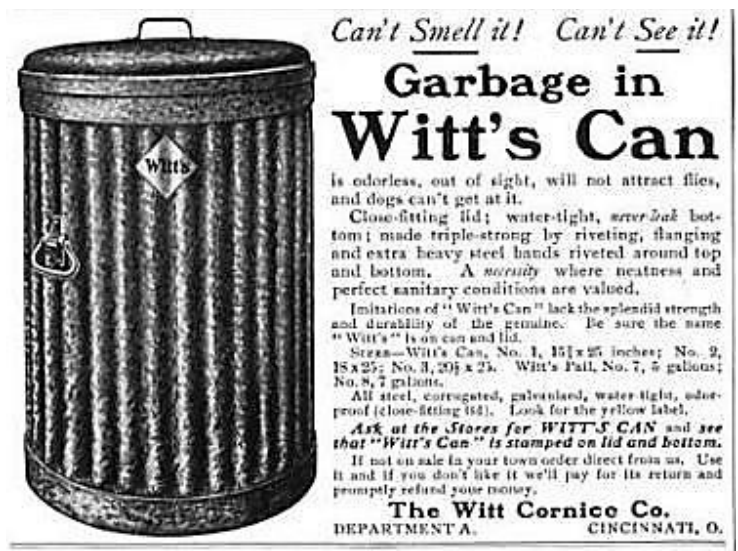

Figure 2. Trash Can Advertising

Source: https://www.izito.ws/Metal Trash Can

The trash can consist of two parts, namely: at the top of which is a cover, serves as a hole inserting garbage, protecting garbage from various types of weather, while reducing the impact of pollution. While at the bottom serves as a container. In its development, various types or forms of trash cans introduced can be found in a number of regions. Trash cans are distinguished by categorization of the type of litter through shape, and color. The trash can that has been through the modification process, namely by adding features and accessories. Not only that, the use of materials and manufacturing techniques are also of particular concern in distinguishing trash cans.

\section{Product Aesthetics}

The product visually has elements that support its aesthetic appearance, such as shape, color, texture, size, proportions, and other elements. Aesthetics in a product is very valuable to humans as a user, aesthetics has an influence on the human experience when interacting with the product. Aesthetics is one of the most significant features in product design which can influence the success of product in the future market (Bloch, 1995; Herr, 2000). "From follow function" as a popular product aesthetic jargon, about this Montague (n.d). states "It's a circular connection where each leads to the other. The form conveys meaning, the meaning reveals function, and the function drives form. When we recognize the link between form, function, and meaning, we see how aesthetics plays an essential role in the user experience".

Human beings and their interactions with products occur every day, human beings as an audience will have conclusions about the design of the product, how it experiences with a particular product. Designers in this case prioritize the experience of audience interaction to visual aesthetics in addition to function. The concept of visual product aesthetics usually plays 


\title{
Aesthetic Study of Malioboro Yogyakarta Trash Can
}

\author{
Ifan Rohimanto \& Yeffry Handoko Putra
}

a basic role for ideas about the sensorial character of the products (Workman and Caldwell, 2007). Furthermore, visual aesthetics is one of the most important factors affecting consumer perception in many ways (Mumcu and Kimzan, 2015).

Kieran (1997) stated aesthetics as a value, this opinion can be interpreted as a product design has the value of aesthetic content in it. However, usually the audience always prioritizes the taste of the aesthetics of the product rather than following the function of the product. Thus, unlike beauty, attraction is an indirect response to what human beings can perceive based on numbers of factors that have been already discussed. In this situation, the beauty preference and human reactions have been relatively determined. (Khalighy, Green, and Whittet, 2012). In this situation, the user has gradually believed that the expected function can only be possible with this specific design (Hekkert, 2006).

Product design with consideration of design shape, color, size, is a creative effort made by the designer, to meet the needs of the experience of audience interaction with the aesthetics and functions of a particular product. The product is always required to have novelty and attractiveness, in this case Crilly et al. (2004) states Although the novelty is an effective factor in increasing the attraction of product, the aesthetic perfection cannot be achievable in the absence of concinnity (beauty). Aesthetics in Product design is a significant factor in developing a new product (see Figure 3). The product which prospers functionally and visually will differentiate us from the competitors. It is not easy to integrate our requirements and specifications in to a customer perceived product design, there arrives dissension. A detailed market research will give you the perceived customer value. By overwhelming dissension will result in the exemplary product. (Eg: shape, colour, pattern, size, decorations etc.)

Thus, not only the function, beauty and attractiveness of the product is a direct response to what human beings can feel towards the product, aesthetic factors play a greater role in influencing human beings as an audience or consumer in determining the choice of products used, so that product manufacturers through designers provide a large aesthetic portion of the products made.

\section{Aesthetics of Malioboro Trash Can}

Malioboro area is located in the middle of the city center of The Special Region of Yogyakarta, as a tourist area of Malioboro, along Malioboro street, on the right and left side of the street is equipped with wide sidewalk facilities, so that pedestrians or tourists can enjoy a tour through the area. As a tourist area, the management of environmental beauty becomes important, comfort facilities such as chairs, parks, decorative lamps and hygiene facilities such as trash cans, their existence is adapted to the environment. Malioboro trash can is designed to fit the environment, the choice of shape, material and color becomes important because it is made for the audience who visit Malioboro. 


\title{
Aesthetic Study of Malioboro Yogyakarta Trash Can
}

\author{
Ifan Rohimanto \& Yeffry Handoko Putra
}
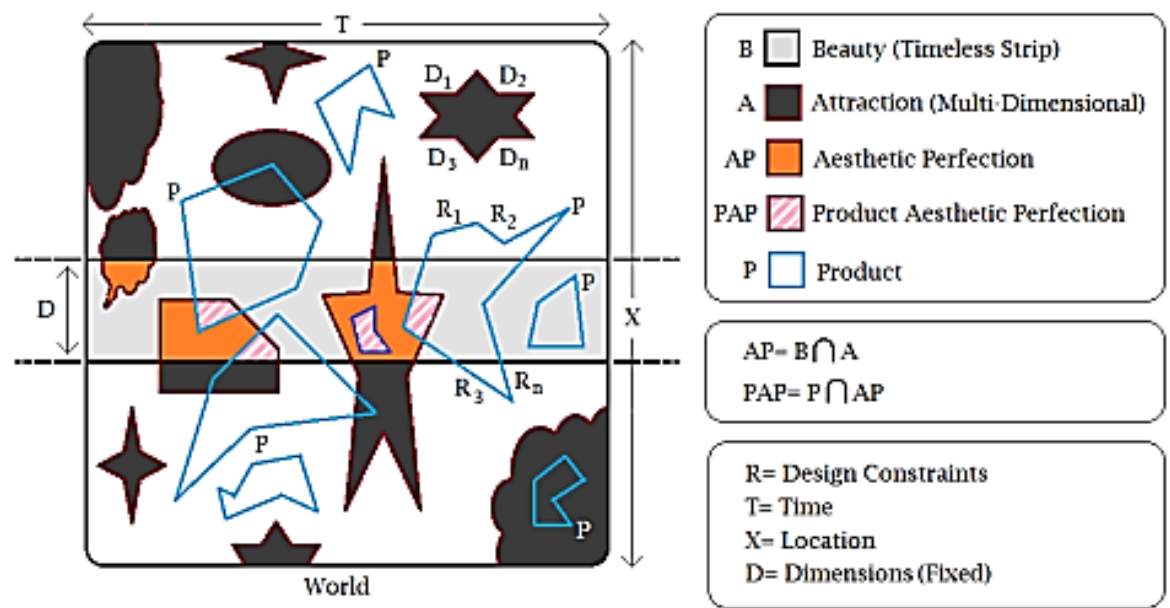

Figure 3. Illustration of Product Aesthetic Perfection

Source: Khalighy, S., Green, G., Whittet, C. (2012). Product Aesthetics and Creativity. The 2nd International Conference on Design Creativity (ICDC2012) Glasgow, UK, 18th-20th September 1.

Trash cans located in the Malioboro area as a sidewalk facility of tourist areas are certainly designed with aesthetic considerations, the trash can not only serves as a garbage container also has aesthetic value. "All human works, whether intentionally created with the awareness of beauty or not, should have the smallest value of beauty. Starting from household appliances, work tools, transportation equipment, fashion devices to forms of residence and other functional items." (Sanyoto, $2009: 3$ )

Anatomically, the trash can in Malioboro sidewalk consists of two parts, namely the lid with aluminum and the container made of Terrazzo. The lid of the trash can is made using traditional techniques, namely kenteng technique. Made by Yogyakarta craftsmen. For a craftsman (kriawan), his work in addition to functioning, must also have beauty. In the workshop, the lids and bodies of this trash can are made by craftsmen who have special skills, to turn the material into a can be enabled and high value with simple tools owned (Widagdo 2011: 124). Trash lid is an object created by using kenteng technique (forging or punching) on aluminum type metal, through the process of making aluminum material forged until the shape follows the desired shape. Kenteng technique is a traditional technique, as a wealth of local traditions used by the government of The Special Region of Yogyakarta. According to Sumarjono (2005), aesthetic considerations based on the richness of artistic traditions in Indonesia should be able to produce industrial products that are more varied in appearance. 


\section{Aesthetic Study of Malioboro Yogyakarta Trash Can}

\section{Ifan Rohimanto \& Yeffry Handoko Putra}
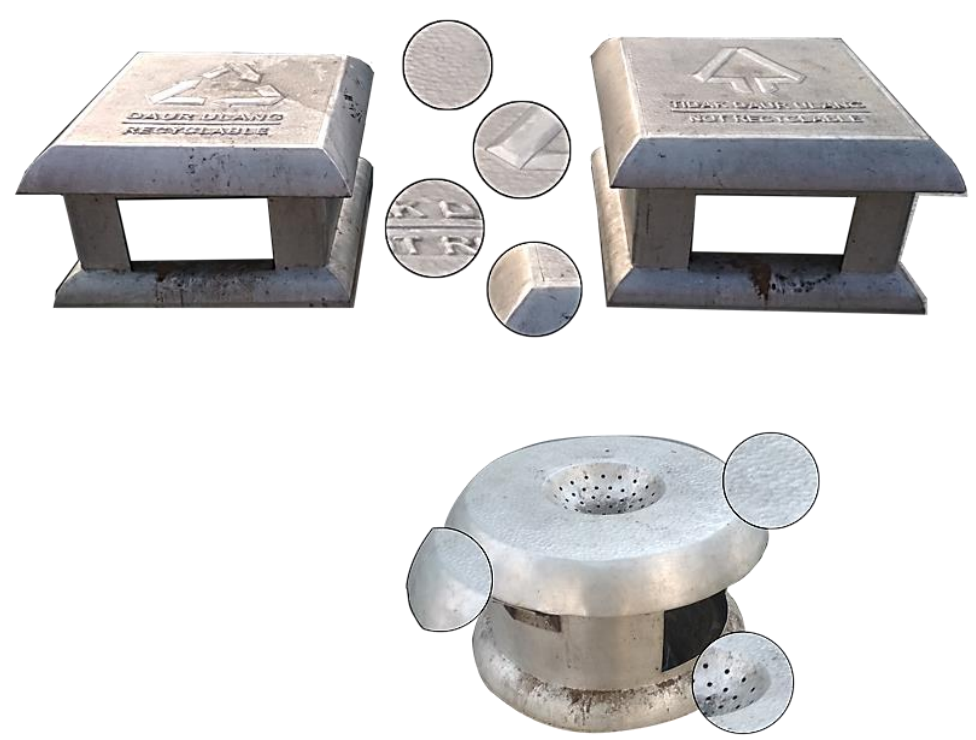

Figure 4. Close the trash can in Malioboro area using Aluminum material and use kenteng technique (traditional forging).

Source : Author Documentation.

Kenteng technique is a Javanese term, or in Indonesian is known as the punch technique, which means the formation of a manual in turning a metal material into a desired form by being hit continuously. Kenteng technique is a technique that has long been used, one of which is in the manufacture of traditional gong instruments (Hartono, 2020). There is no source of literature that writes the history of kenteng technique. Kenteng technique is believed by the people of Yogyakarta has been used and known for a long time. Each country has its own traditional forging and characteristics in the use of these techniques, and one of them in Indonesia is in Kotagede, Yogyakarta. In addition to trash cans, there are several other objects made by kriawan (craftsmen) Kotagede with the use of kenteng techniques, including accessories, project helmets, musical instruments, and furniture. A distinctive feature of this technique lies in the convex/concave form produced on metal, aluminum, copper, or brass materials.

In the process of making, a special plinth is required that has an unusual texture that is: not hard, does not clot, and looks like flour. The plinth can be found in the area under the bamboo tree. The manufacture of this trash can uses aluminum as a staple material. The aluminum to be used should have a thickness of 0.8 (zero point eight) to one centimeter. It is intended to avoid fragility and holes in the material. 


\section{Aesthetic Study of Malioboro Yogyakarta Trash Can}

\section{Ifan Rohimanto \& Yeffry Handoko Putra}

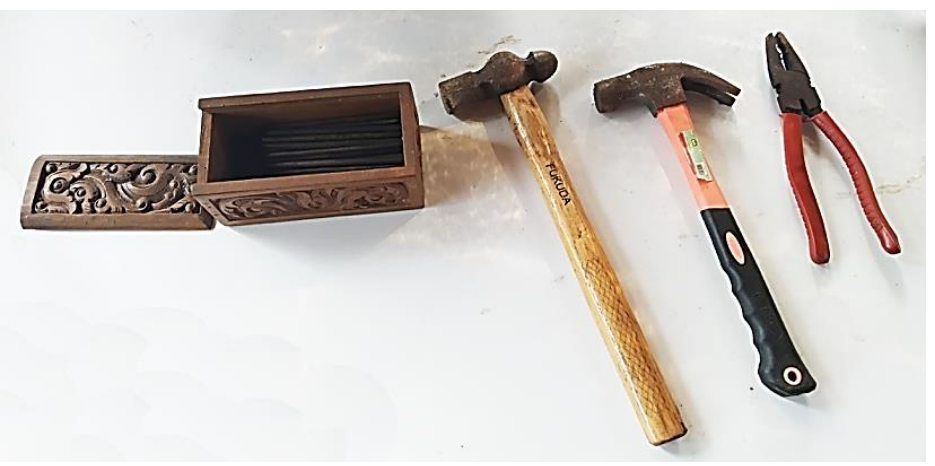

Figure 5. Some of the tools used in the manufacturing process, from the left: pegs, konde hammers, goat iron hammers, and pliers.

Source: Author Documentation.

Then in the next stage is to make "Jabung". Jabung is a mixture produced from red brick powder, gum resin, and used oil or cooking oil. Jabung should be cooked until boiling and obtained a texture like porridge. Then the dough is put in a bucket containing cold water. It is intended to test the density of the dough. If the texture of the dough is still soft, it is necessary to re-mix it with red brick powder. Jabung function itself is as an ingredient mixed with a plate to produce detail on the plate / material when doing kenteng until it becomes a shape.
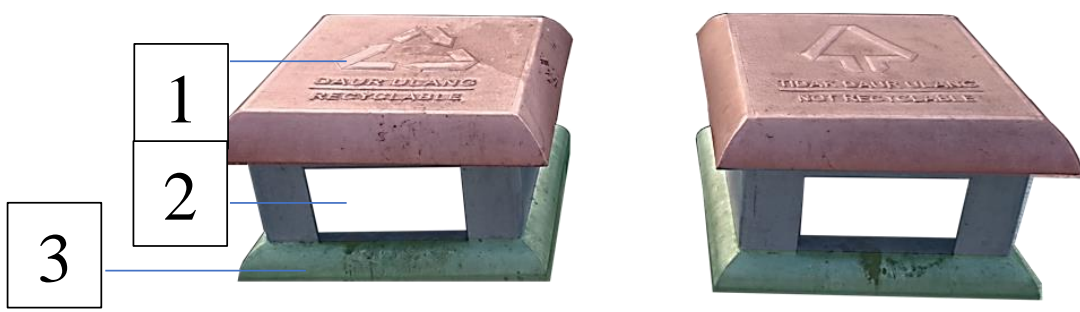

Figure 6. Distribution of trash can lids

Source: Author Documentation.

To realize the square shape as in Figure 6, then the lid of the trash can is divided into three parts to realize a precise shape. Not all of them use kenteng technique, but from some parts it is then combined using welding machine. In contrast to the round shape, with a calculation and the way that craftsmen can be formed directly with kenteng technique. On the plate that has been filled with jabung, then jabung removed with blow torch, cleaned using water, and then brushed using a wire brush until clean. 


\section{Aesthetic Study of Malioboro Yogyakarta Trash Can}

Ifan Rohimanto \& Yeffry Handoko Putra

At the completion stage, to polish the metal, can use green Terrazzo in a polished way. After that, the metal is wrapped using a dim coting (doff) that is not glossy. Then to form a wavy texture and written captions on the top of the lid of the trash can, used a chisel technique with a konde hammer tool (round part), see Figure 4 and 7. It is also worth noting that the kriawan, each creating their own tool creations. This is done to facilitate the work, as well as rail trains used by some kriawan as a foundation in kenteng activities.
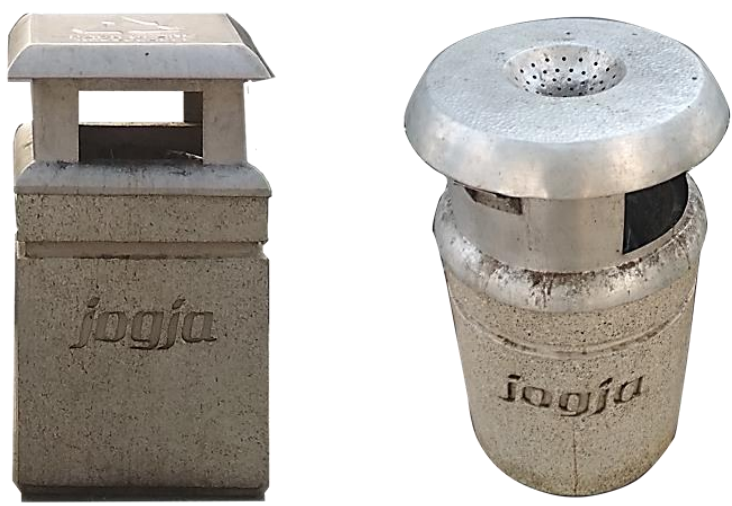

Figure 7. Two series of trash cans in total.

Source: Author Documentation.

Malioboro trash can has aesthetic value, the use of trash cans for sidewalk tourist areas, shapes, colors and materials are formed in accordance with the environment, therefore the aesthetic value needs to be reviewed. Beauty based on its definition should be a timeless reality which has remained unchanged over time. The perception of beautiful objects can be a rational relationship between the design elements based on mathematical rule which is called design principles (Khalighy, Green, and Whittet, 2012).

The following is an analysis of aesthetic value through four indicators, namely color, shape, texture, and proportion based on aesthetic methods from Dr. Dharsono, M.Sn (Sony Kartika) : 


\section{Aesthetic Study of Malioboro Yogyakarta Trash Can}

Ifan Rohimanto \& Yeffry Handoko Putra

Table 1. Malioboro Trash Cans Analysis

\begin{tabular}{|c|c|c|c|}
\hline No. & Indicator & Description & Image \\
\hline 1. & Colors & $\begin{array}{l}\text { Trash cans are dominated } \\
\text { by dark gray color or } \\
\text { known as gray dove. Color } \\
\text { is a natural color derived } \\
\text { from the selection of } \\
\text { materials. At the top, it uses } \\
\text { aluminum metal, while at } \\
\text { the bottom it uses Terrazzo } \\
\text { mixed with natural } \\
\text { materials of sand or ash of } \\
\text { Mount Merapi. The } \\
\text { intensity of the color at the } \\
\text { top looks higher, this can } \\
\text { be observed from the smell } \\
\text { of aluminum material that } \\
\text { appears due to the presence } \\
\text { of light exposure. While in } \\
\text { the body part of the trash } \\
\text { can, tends to have more low } \\
\text { intensity. }\end{array}$ & \\
\hline 2. & Form & $\begin{array}{l}\text { Overall, the shape of the } \\
\text { trash can displayed looks } \\
\text { very simple. The difference } \\
\text { between the two sets of } \\
\text { trash cans lies in the basic } \\
\text { shape. In figure } 7 \text {, each } \\
\text { artifact has a square and } \\
\text { cylindrical base shape. In } \\
\text { this case, the use of } \\
\text { kenteng, welding, and } \\
\text { carving techniques can be } \\
\text { seen in the writing, logo, } \\
\text { symbols, and curved sides } \\
\text { of artifacts. The shape of } \\
\text { the cover on the series of } \\
\text { square trash cans has } \\
\text { similarities with the shape } \\
\text { of the roof of the house, as }\end{array}$ & \\
\hline
\end{tabular}

Copyright (c) 2020 Ifan Rohimanto, Yeffry Handoko Putra (c) (i) (9) 
Ifan Rohimanto \& Yeffry Handoko Putra

\begin{tabular}{|l|l|}
\hline Texture & $\begin{array}{l}\text { well as its function. } \\
\text { However, unlike the series } \\
\text { of cylindrical trash cans } \\
\text { that have similar shapes } \\
\text { with gong instruments, the } \\
\text { shape of the arch in the } \\
\text { function as an ashtray. } \\
\text { Seen in figure 1 and figure } \\
\text { 4, both sets of trash cans } \\
\text { have a natural texture that } \\
\text { arises from the material } \\
\text { used. Textures can be seen } \\
\text { on the body of the trash } \\
\text { can, in the form of dots that } \\
\text { form an abstract geometric } \\
\text { pattern. Texture is formed } \\
\text { by terraso material and } \\
\text { merapi ash sand used. } \\
\text { Meanwhile, on the top } \\
\text { cover of the trash can, the } \\
\text { use of aluminum-type metal } \\
\text { materials combined with } \\
\text { chisel techniques, forming } \\
\text { small arches or wavy } \\
\text { textures. }\end{array}$ \\
\hline $\begin{array}{l}\text { The laying of trash cans on } \\
\text { the side of the pedestrian } \\
\text { path area, is between two } \\
\text { park benches and two trash } \\
\text { cans placed side by side. } \\
\text { Both sets of trash cans have } \\
\text { a balanced proportion. } \\
\text { Height and width } \\
\text { adjustments are also } \\
\text { tailored to the user's needs. } \\
\text { While the size of the size is } \\
\text { related to the estimated } \\
\text { capacity of the amount of } \\
\text { waste, which is thus very } \\
\text { suitable placed on the } \\
\text { pedestrian path. }\end{array}$ \\
\hline 4.
\end{tabular}




\title{
Aesthetic Study of Malioboro Yogyakarta Trash Can
}

\author{
Ifan Rohimanto \& Yeffry Handoko Putra
}

The aesthetic in Malioboro trash can consists of natural colors derived from the material, namely aluminum on the lid of the trash can and terrazo material mixed with sand on the bottom / container. The shape consists of two kinds of shapes, namely square and round, the texture is created from Terrazzo material mixed with sand, so that it produces a speckled texture, the proportions are balanced, adjusted to the average height of the Indonesian population with a balanced width as well. Users can use the trash can without difficulty due to the ideal proportions. In this case Wagner (1999), stated An aesthetic response has affective and cognitive dimensions as well as sensory such as involuntary physical response. Design becomes an important factor in a product, Nowadays, visual product aesthetics has become an important factor which designers and managers have to pay more attention. The concept of product aesthetics affects many factors both directly and indirectly. (Mumcu and Kimzan, 2015).

\section{Conclusion}

The promotion of Malioboro tourism area as an area that has the privilege and comfort of the community in conducting activities are two aspects that become the goal in revitalizing the area, including the reorganization of urban spatial and pedestrian areas. Revitalization of Malioboro Yogyakarta area is carried out by carrying the theme of urban contemporary plaza or contemporary city square. Contemporary terms in architecture relate to concepts and styles of the present or update. Revitalization is carried out focusing not only on the spatial layout of the city, but also related to the construction and arrangement of street furniture / street furniture, which is a public facility of malioboro pedestrian path, one of which is the addition of trash cans.

Both sets of trash cans have a simple look, visible from the archear in the form of squares and cylinders. Each side has a mix of straight lines and curved corners. The overall shape has similarities with the roof of the house and gong instruments, but it is equipped with an in-out arch that functions as an ashtray. The roof on the cover as its function is used protects garbage from various types of weather.

The choice of color palette in contemporary design style is dominated by neutral colors such as gray, black, brown, and white. These colors are natural colors due to the use of materials in the form of natural terraces, sand, and metal. The contrast ratio in both series is a harmonious combination of two colors intensities. The color intensity that have on the cover is higher than the body part, so it can be said to fill each other and maintain contrast.

Wavy texture and the appearance of letters and symbols that materialize on the surface of the lid of the trash can series is an artificial texture formed using chisel techniques, while the texture of the dots that form geometric patterns on the body of the trash can is formed naturally. Judging 


\title{
Aesthetic Study of Malioboro Yogyakarta Trash Can
}

\author{
Ifan Rohimanto \& Yeffry Handoko Putra
}

from the aesthetic aspects, the combination of textures of these two sets of trash cans is intended to provide antique and classic value.

A series of square bins along the pedestrian path area, placed side by side (organic and inorganic trash can) and adjacent to the seat, in contrast to the cylindrical trash can that is only placed in some non-smoking areas. The difference lies in the size of the cover part which is slightly larger when compared to the body part. However, both circuits have a balanced proportion that can be seen from the combination of the cover and the body part of the trash can so that it can function optimally.

The use of natural materials such as aluminum, 228errazzo, and sand, in addition to adding aesthetic value also provides value benefits in the form of durability and makes it easier for users to take care and clean it (product care). In addition, the arches contained on the sides of the lid of the trash can produced kenteng technique, improving the safety aspect of the object. This is because if there is a road infrastructure that has a sharp edge, it will be dangerous for its users.

\section{Referances}

Bandem, I Made. (2002). Mengembangkan Lingkungan Sosial Yang Mendukung Kriya Seni. Makalah Seminar Internasional Seni Rupa, Program Pascasarjana ISI Yogyakarta.

Blijlevens, J., Carbon, C.C., Mugge, R., Schoormans, J.P.L.(2012). Aesthetic appraisal of product designs: Independent effects of typicality and arousal, British Journal of Psychology $103,44-57$

Bloch, P.H.(1995).Seeking the ideal form: Product design and consumer response, Journal of Marketing 59, 16-29

Crilly, N., Moultrie, J. \& Clarkson, P. J. (2004). Seeing things: consumer response to the visual domain in product design, Design Studies, 25(6), 547-577.

Cox, D.,Cox, A.D. (2002). Beyond first impressions: The effects of repeated exposure on consumer liking of visually complex and simple product designs, Journal of the Academy of Marketing Science 30, 119-130.

Gusma (2020) : wawancara tempat sampah malioboro setelah revitalisasi. Yogyakarta

Hartono, Budi (2020) : wawancara definisi, alat \& bahan, proses pembuatan benda menggunakan Teknik kenteng. Yogyakarta

Haryono, Timbul (2002) : Terminologi dan Perwujudan Seni Kriya Masa Lalu dan Masa Kini ebuah Pendekatan Historis-Arkeologi. Makalah. Yogyakarta: ISI Yogyakarta 


\title{
Aesthetic Study of Malioboro Yogyakarta Trash Can
}

\author{
Ifan Rohimanto \& Yeffry Handoko Putra
}

Hekkert, P. (2006). Design aesthetics: principles of pleasure in design, Psychology Science, 48(2), 157-172.

Herawati Lucky dan Amri Choirul (2017) : Penggunaan Tempat Sampah Bermotif Terhadap Perilaku Buang Sampah Pada Tempatnya Di Sekolah Dasar Negeri Wilayah Argomulyo, Sedayu, Bantul. Yogayakarta

Herr, P. M. (2000). An Investigation of the Processes by Which Product Design and Brand Strength Interact to Determine Initial Affect and Quality Judgments, Journal of consumer psychology, 12(2), 133-147.

Hills, J. (2019). Taking Out The Trash - A History of Trash in Western Civilization. Retrieved 4 September 2020, from https://www.mantripping.com/stuff/all-about-trash-cans.html

Jurang007. (2020). Manfaat Tempat Sampah yang Belum Diketahui Oleh Masyarakat | zonaseru.id. Retrieved 4 December 2020, from https://www.zonaseru.id/artikel/manfaattempat-sampah-yang-belum-diketahui-oleh-masyarakat

Kartika, Dharsono Sony (2007) : Kritik Seni, Institut Teknologi Bandung, Bandung

Kieran, M. (1997). Aesthetic value: beauty, ugliness and incoherence, Philosophy, 72(281), 383 - 399.

Kim Mr, Youngduk (2015) : Masters Theses Exploration Of Connection Of Connectivity Between Urban Pl Ween Urban Plaza And Mixed Use Buildings, University of Massachusetts Amherst

Kota Yogyakarta, P. (2020). Visi Dan Misi. Retrieved 4 December 2020, from https://www.jogjakota.go.id/pages/visi-dan-misi

Leblance, R. (2020). The Art of Choosing the Right Trash Can. Retrieved 4 December 2020, from https://www.thebalancesmb.com/trash-can-selection-and-maintenance-4126302

Moleong, J Lexy. (2006). Metodologi Penelitian Kualitatif (edisi revisi), Bandung

Montague, Monty. (n.d). The Amazing Role of Aesthetics in Product Design .White Paper.

Mumcu, Yigit., Kimzan, Halil Semih. (2015). The Effect of Visual Product Aesthetics on Consumers' Price Sensitivity. Procedia Economics and Finance 26, 528 - 534. 4th World Conference on Business, Economics and Management, WCBEM

Newkirk, D., Crainer, S.,(2003). Management Lessons from Modern Wars, Strategy and Business 32, http://www.strategybusiness.com/media/file/sb32-fall_03-briefs.pdf (19.03.2015)

Rahman, Fahzy Abdul. (2014). Reduce, Reuse, Recycle: Alternatives for Waste Management. Cooperative Extension Service, College of Agricultural, Consumer and Environmental Sciences. New Mexico State University

Copyright (c) 2020 Ifan Rohimanto, Yeffry Handoko Putra

(c) (i) (8) 


\section{Aesthetic Study of Malioboro Yogyakarta Trash Can}

Ifan Rohimanto \& Yeffry Handoko Putra

Sanyoto, E, Sudjiman (2009) Nirmana, Elemen-elemen Seni dan Desain, Yogyakarta

S. Khalighy, S., Green, G., Whittet, C. (2012). Product Aesthetics and Creativity. The 2nd International Conference on Design Creativity (ICDC2012) Glasgow, UK, 18th-20th September. 1 School of Engineering, University of Glasgow, Glasgow, UK 2Department of Product Design Engineering, Glasgow School of Art, Glasgow, UK.

Soedarso Sp, (2006): Trilogi Seni, Penciptaan Eksistensi dan Kegunaan Seni, BP. Institut Seni Indonesia, Yogyakarta.

Sugiono. (2011) Metode Penelitian Kualitatif Kuantitatif dan R\&D, Bandung

Sumartono, (2005) : Jurnal Pertimbangan Estetika Dalam Desain Produk Industri, Institut Seni Indonesia, Yogayakarta

Wagner, J., (1999). Aesthetic value In Consumer value: A framework for analysis and research, edited by M. B. Holbrook, Routledge, New York.

Weggeman, M., Lammers, I., Akkermans, H.,(2007). Aesthetics from a design perspective, Journal of Organizational Change Management 20,346-358.

Widagdo, (2011): Buku Desain \& Kebudayaan, Institut Teknologi Bandung, Bandung

Wispul (2012): Staf Pengajar Program Studi Kriya Seni, Jurusan Kriya, Fakultas Seni Rupa, Institut Seni Indonesia, Yogyakarta.

Workman, J.E., Caldwell, L.F., (2007). Centrality of visual product aesthetics, tactile and uniqueness needs of fashion consumers, International Journal of Consumer Studies 31, 589596. 